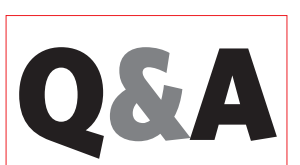

A long-time executive with Merck \& Co, Jeffrey Sturchio recently took over as president and chief executive of the Global Health Council.

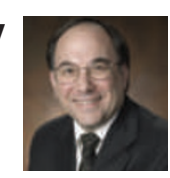

Did serendipity play a part in your career path?

Yes. I had no experience with international companies when I started at Merck as a company historian and archivist. It was a leap in the dark but also the opportunity to learn. From my initial role I was able to move into working with science policy. If I had pursued a master's degree in public health right after college, I'm not sure I would have been able to have as much impact.

\section{What is the biggest} challenge you face at the Global Health Council? There are relatively few questions in global health for which we don't already have answers. We know how to prevent HIV transmission from mother to infant and what the appropriate treatments are for malaria. The real challenge is making sure that the people who know the answers are brought together with those who can implement them. Our goal is to organize the diverse expertise from all corners of the global-health communities.

\section{What career accomplishment are you most proud of?}

The role I had in helping millions of people get access to essential medicines. At Merck, we developed a programme that enabled hundreds of thousands of people in Africa and other parts of the developing world to obtain access to life-saving HIV medicines. We also had a programme to help 100 million people each year get free treatment to prevent river blindness and lymphatic filariasis.

\section{What is the secret to your} success?

I listen to people. It's no more complicated than that. If you want to solve a given problem, seek out experts and community members, listen carefully to what motivates them and what resources they need. Then find ways to establish common ground and bring together complementary skills. You don't have to agree on everything with work towards a common goal if it is mutually beneficial.

\section{Where do you find inspiration?}

By getting out in the field and seeing health-care providers on the front lines of global health. It is amazing to watch people providing health care in refugee camps in the middle of nowhere with just basic materials, a shoestring budget and a lot of heart. The commitment and passion of these front-line workers - and the hope they bring - is deeply inspiring.

\section{Have current global-health} efforts made an impact? Yes. The attention and resources flowing from global-health communities are creating tremendous excitement. We hope that the prevention of maternalfetal HIV transmission will soon increase from $33 \%$ to $80 \%$ once the necessary resources are put in place.

\section{Interview by Virginia Gewin}

your partners, but you can

\section{IN BRIEF}

\section{US visa policy under fire}

A statement from 31 academic and research associations in science and engineering urges the US federal government to streamline its visa process for international scientists, scholars and students. The 10 June statement, sent to several federal agencies, also called for a panel to be formed to review all federal visa policies and procedures enacted after the terrorist attacks of 11 September 2001 The group acknowledged improvements to the visa process, but said that delays are increasing. Its recommendations include a 30-day review for short-term applications from qualified researchers, scientists and graduate students and shorter processing for prominent repeat visitors.

\section{The best places to work}

Biotech firms Genentech and Monsanto, along with the University of Pennsylvania, were among the top five employers in an online poll ranking the 100 best places to work in the United States for informationtechnology professionals.

The poll, conducted by Computerworld magazine, ranks the 100 organizations on the basis of such criteria as training, job security, diversity and benefits. Genentech, based in South San Francisco, California, won kudos for its benefits plan and leadership programmes; Monsanto of St Louis, Missouri, gained a high rank for its flexible work hours and telecommuting policy; and the University of Pennsylvania in Philadelphia won praise for its benefits, diversity and secure-campus practices. Now in its 16th year, the survey collected responses from more than 27,000 employees across the United States.

\section{Student gender bias}

chaos - and there's not a

thing I can do about it

To help pay my way through graduate school, I worked

in a women's clothing shop.

During my sales training, the boutique owner pointed her

finger at my chest. "Julia, you have to hustle!" she insisted.

"And to hustle, you have

to focus."

Her message - that to succeed I must stay sharp and on task - has stayed with me. Her voice resonates with me this month as I find myself haemorrhaging work hours thanks to childcare

\begin{tabular}{|c|c|}
\hline $\begin{array}{l}\text { responsibilities. } \\
\text { The twice-daily day-care } \\
\text { commute eats up precious } \\
\text { work time and shortens } \\
\text { my workday. My son's } \\
\text { regular mingling with other } \\
\text { children has also exposed } \\
\text { him to a host of germs and } \\
\text { necessitated my taking time } \\
\text { off work for doctor's visits and } \\
\text { at-home nursing care. I've } \\
\text { been prey to some of these } \\
\text { day-care 'superbugs', too. } \\
\text { All of this has wiped out my } \\
\text { productivity. } \\
\text { So where is my focus, other } \\
\text { than on how inefficient I feel } \\
\text { at work these days? Without } \\
\text { a doubt, my attention and }\end{array}$ & $\begin{array}{l}\text { energy centre on my son's } \\
\text { proper care and development. } \\
\text { But the rest of my focus is } \\
\text { splattered like baby food on } \\
\text { the ceiling. } \\
\text { With a multitude of ongoing } \\
\text { lab projects and papers that, } \\
\text { to my impatient self, advance } \\
\text { as if through thickest jelly, I } \\
\text { need to regroup, buckle down } \\
\text { and hustle. Otherwise, my } \\
\text { focus will be on what I want } \\
\text { to do rather than on my actual } \\
\text { successes and what I can } \\
\text { reasonably achieve. } \\
\text { Julia Boughner is a postdoc in } \\
\text { evolutionary developmental } \\
\text { biology at the University of } \\
\text { Calgary, Canada. }\end{array}$ \\
\hline
\end{tabular}

responsibilities

twice-daily my workday. My son's regular mingling with other children has also exposed him to a host of germs and necessitated my taking time ork for doctor's visits an ' All of this has wiped out my productivity.

So where is my focus, other at work these days? Without Calgary, Canada.
In the United Kingdom, more women than men are gaining admission to university, and they are more likely to stay once they get there, according to a study by the Higher Education Policy Institute. The Oxford-based non-profit group's report, Male and Female Participation and Progression in Higher Education, found that almost half of all women aged 17-30 attend college full- or part-time, compared with just over one-third of men 17-20 drop out, compared with $6.5 \%$ of women the same age, and $17 \%$ of men aged 21-30 drop out, compared with $12.3 \%$ of women the same age. of the same ages. About $8 \%$ of men aged 